\title{
Hukou and Non-hukou Migrations in China: Comparisons and Contrasts
}

\author{
Kam Wing Chan, ${ }^{1 *}$ Ta Liu ${ }^{1}$ and Yunyan Yang ${ }^{2}$ \\ ${ }^{1}$ Department of Geography, University of Washington, Seattle, USA \\ ${ }^{2}$ Zhongnan University of Finance and Economics, China
}

\section{ABSTRACT}

This paper uses China's 1990 Census 1\% microdata and studies interprovincial migration with reference to a core Chinese socioeconomic institution, the household registration (hukou) system. We first compared the socioeconomic characteristics and geographical patterns of long-distance hukou and non-hukou migratory flows, and developed a framework of dual migration circuits. With this framework, we used a statistical model to evaluate migration rates in relation to both origin and destination variables. It was found that these two types of migrants shared some general demographic characteristics, but displayed substantial socioeconomic differences. Hukou migrants tended to originate in urban areas, had an extremely high share of the college-educated and were employed in more skilled jobs, while non-hukou migrants were mostly from rural areas with much lower education attainment. Hukou labour migrants tended to move through government and formal channels, while non-hukou migrants relied on their own, often informal, sources for jobs. We used a set of place-to-place migration models to assess the differential effect of the same variables on different types of migration. While hukou and non-hukou migration (including rural labour migration) were, as expected, deterred by distance and moved mostly to more economically developed coastal provinces, the

\footnotetext{
* Correspondence to: Kam Wing Chan, Department of Geography, University of Washington, Box 353550, Seattle, WA 98195-3550 USA. E-mail: kwchan@u. washington.edu
}

migration mechanisms and degree of the impact were not the same. Non-hukou migration rates were tied positively to the migration stock, a process consistent with a networked migration hypothesis, while hukou migration rates were not. Rural labour migrants moved away from provinces of high population pressure to those with more favourable ratios of land per labourer, in line with neoclassical predictions. Hukou migration moved in the opposite direction, reflecting a different set of factors at work. Our analysis indicates that the hukou system remained a relatively powerful institution in structuring migration in the 1980s. The study also illustrates the usefulness and limitations of applying existing migration models in a different sociopolitical context. Copyright (C) 1999 John Wiley \& Sons, Ltd.

Received 16 March 1999; Revised 29 July 1999; Accepted 20 August 1999

Int. J. Popul. Geogr. 5, 425-448 (1999)

Keywords: China; dualism; hukou system; labour; migration; model

\section{INTRODUCTION}

fter decades of being bound to home
villages or assigned to life-long jobs,
many Chinese started to taste the new freedom of mobility in the 1980s. Most notable was the massive labour exodus from the countryside, called 'mingong chao' or 'waves of rural labour'. The importance of this new phenomenon has been equated to that of the rural decollectivisation in the early years of the 
post-Mao reform (Gong, 1994), as the increased population mobility has gradually reshaped some of the fundamentals on which Chinese society and economy were based, and with many consequences yet to be fully studied and understood (Kelliher, 1992; Smith, 1996; Zhou, 1996). The study of recent migration in China has also posed special challenges. As remarked elsewhere, it is like 'xiazi moxiang' (the blind feeling an elephant), especially considering all the obstacles posed by the diversity of groups involved in migration, the special definitional intricacies and measurement problems, and the lack of a ready analytical framework (Goldstein and Goldstein, 1987b; Chan, 1994, 1999).

The current paper intends to contribute to the growing body of literature on Chinese migration by incorporating the hukou (household registration) system, one of the main Chinese socioeconomic institutions, in the analytical framework, and by explicitly addressing the hukou system and the resultant migration patterns. The paper takes advantage of the availability of a large migration microdata set from the 1990 Census. In the next section, we will first review the existing migration literature and tease out the relevance to the Chinese case. An explanation of the framework developed for analysing the Chinese macro-migration patterns is provided. We believe that such a framework enables us to identify the migration patterns and the underlying factors more effectively. Various postulates about migrants' behaviours in relation to the contextual factors of both the origin and destination are scrutinised. The conclusion summarises the findings and suggests the relevance of our work to the broader literature. This study provides an opportunity to assess whether Chinese internal migration conforms to some of the general migration behaviours seen elsewhere.

\section{LITERATURE REVIEW AND ANALYTICAL FRAMEWORK}

Migration within and from China existed in considerable numbers in the pre-1978 period, but as a research subject was almost totally neglected if not forbidden. ${ }^{1}$ Very little information on migration was available during this period (Chan and Yang, 1996). Since economic reform in 1979, a large amount of data have become available through various surveys at different spatial scales, including the censuses, national-scale population surveys and more specialised migration surveys (see Mallee, 1996; Chan, 1999). Researchers both inside and outside China have examined many aspects of Chinese migration, including the volumes of migration and descriptive accounts of social and economic characteristics of migrants and geographical patterns (e.g. Goldstein and Goldstein, 1987a, 1990, 1991, 1993; Chan, 1988; Li and Hu, 1991; Shen and Tong, 1992; Day and Ma, 1994; Ding, 1994; Xu and Gu, 1994; Yang, 1994; Sha, 1995; Shen, 1995; Chang, 1996; Davin, 1999), and the determinants of migration based on census or survey data (e.g. Qian, 1996; Liang and White, 1997; Ma and Liaw, 1997; Rozelle et al, 1997; Fan and Huang, 1998; Hare, 1998). A number of studies have begun to look at migration with reference to social institutions such as the hukou system (e.g. Mallee, 1988; Christiansen, 1990; Yang and Goldstein, 1990; Tan, 1993; Yang, X. 1993; Yang, Y. 1996; Chan, 1996b; Wang and Zuo, 1997; Wang, 1997; Li and Siu, 1997; Solinger, 1999), as well as the impact of migration on the economy and society and related policy issues (e.g. Solinger, 1995b, 1999; Nolan, 1993; Wan, 1995; Chan, 1998). There is also a huge quantity of studies related to Chinese rural-urban migration and policies, subsumed under the rubric of 'urbanisation' studies (see e.g. Chan, 1994). These studies have shed light on many aspects of Chinese migration, as well as providing useful pointers for further research.

Based on the existing literature and adopting a dualistic framework espoused by Chan (1996a) and Wang (1997), this paper aims to analyse a 'structural' aspect of Chinese migration through the use of interprovincial migration data from a sample drawn from China's 1990 Census. The premise used is that the hukou system, being a major Chinese socioeconomic institution, is important in structuring migration in China. This approach departs from a number of previous studies, which treat all Chinese domestic migrants as one single undifferentiated mass (partly due to lack of disaggregated data) (see Liang and White, 1997; Yan, 1998). Our approach takes into 
Table 1. Hukou and non-hukou rural-urban migrants.

\begin{tabular}{|c|c|c|}
\hline Characteristics & Hukou migrants & Non-hukou migrants \\
\hline $\begin{array}{l}\text { Household registration type and } \\
\text { status }\end{array}$ & Non-agricultural and local & Agricultural and non-local \\
\hline $\begin{array}{l}\text { Entitlements to state-supplied } \\
\text { social benefits and } \\
\text { opportunities }\end{array}$ & Full & $\begin{array}{l}\text { From nil to temporary } \\
\text { entitlements }\end{array}$ \\
\hline Legal urban residency status & Full status & Illegal or temporary \\
\hline Socioeconomic sector & Mostly in the state sector & $\begin{array}{l}\text { Mostly in the non-state sector; } \\
\text { also as temporary workers in } \\
\text { state sector }\end{array}$ \\
\hline Mechanism of effecting migration & $\begin{array}{l}\text { Determined by bureaucratic } \\
\text { decisions within plan limits }\end{array}$ & $\begin{array}{l}\text { 'Spontaneous', based on personal } \\
\text { contacts and market } \\
\text { information }\end{array}$ \\
\hline Stability of moves & Permanent & Seasonal or semi-permanent \\
\hline \multicolumn{3}{|l|}{$\begin{array}{l}\text { Labour characteristics of principal } \\
\text { migrants }\end{array}$} \\
\hline Skill level & Skilled and low-skilled workers & $\begin{array}{l}\text { Mostly unskilled or low-skilled } \\
\text { labour }\end{array}$ \\
\hline Employment type & Mostly permanent jobs & $\begin{array}{l}\text { Temporary or semi-permanent } \\
\text { jobs in non-state enterprises; } \\
\text { or self-employment }\end{array}$ \\
\hline Housing & Same as other urban residents & Low-cost shelters or homeless \\
\hline
\end{tabular}

Source: Chan (1996a).

consideration a macro-force in current Chinese society, the hukou system, and the 'market' components that govern the behaviours of most ordinary people, including many migrants.

To help assess the relevance of existing frameworks to the Chinese case, a brief review of the special characteristics of migration in China is in order. The most significant aspect of migration that has struck many Western scholars is the 'non-voluntary' nature of the process, as noted by Poston and Yaukey (1992: 615). We argue that any meaningful analysis of Chinese migration must start by making reference to the hukou system, which affects migration in many ways. In China migration is heavily regulated and controlled by the state. Those wanting to change residence are required to seek approval from government departments. A change in residence is deemed official and approved only when it is accom- panied by a conversion of one's hukou status to the destination place. This last step is controlled by the Public Security Bureau. The conversion confers de jure, legal residency rights and, most importantly, eligibility for many urban jobs and accompanying subsidised welfare benefits (Cheng and Selden, 1994; Mallee, 1995). Such a change is granted only when there are good reasons, especially when the move serves, or at least is not at odds with, state interests and policies (such as controlling the growth of large cities). In essence, the hukou system in the pre-reform era functioned as a de facto internal passport mechanism.

While approvals for migration because of marriage or for seeking support from a family member within a rural area or within the same level of urban centre are often granted, rural to urban migration was strictly regulated and 
suppressed in the 1960s and 1970s. Most of this type of migration was reserved for bringing in the necessary labour force in support of stateinitiated programmes. Migration to the city was only an ordinary peasant's dream. Today, peasants can move to many places and work as 'temporary' labour, but getting formally registered as full urban residents in a medium-sized or large city is still largely out of reach.

Since migration is selective, and as hukou and non-hukou migrants face starkly different opportunities and constraints, a clear duality of socioeconomic structure exists. Drawing on Chan (1996b), Table 1 summarises this social and economic dichotomy. The hukou status remains an important watershed in the social and economic contours of the migrants. Without local hukou, peasant migrants to cities are excluded from many job openings, especially those in the state sector. Except for a small minority of self-employed entrepreneurs, nonhukou transients are largely confined to temporary or '3-D' (dirty, difficult and dangerous) jobs that are shunned by urbanites. The requirement to have a permit (based on local hukou status) to work in many urban jobs greatly limits the opportunities of the nonhukou migrants. They are most likely to end up in the bottom rungs of the occupational hierarchy, and, typically, physically segregated from and socially marginalised by mainstream society. Because of the paramount importance of the hukou, population flows in China are most meaningfully classified along hukou lines: (a) migration with residency rights (hereafter, hukou migration); and (b) migration without hukou at destination (non-hukou migration). ${ }^{2}$

While no single existing migration model fits the special Chinese situation well, there is apparent similarity to Chinese migration in some aspects of internal and international migration elsewhere, which have been examined through neoclassical economics and historical-structural models (e.g. Chapman and Prothero, 1985; Papademetriou and Martin, 1991; Massey et al., 1993, 1994; Lucas, 1997). From another angle, Chinese migration also bears the characteristics of some other socialist countries (e.g. Brown and Neuberger, 1977; Ofer, 1977; Demko and Fuchs, 1977; Helgeson, 1978; Forbes and Thrift, 1987; Demko and
Regulska, 1987; Ronnas and Sjoberg, 1993). At the macro-level, the nature of the dualistic social structure set up and maintained by the Chinese 'socialist' state is strikingly similar to that in capitalist societies posited by historicalstructuralist theories (Portes and Walton, 1981; Castells and Portes, 1989). This is central to understanding how labour migration is structured and controlled, and to the resultant socioeconomic segmentation. The broad outcomes and character of segmentation in China are akin to what has been stated in segmented labour market theory: a bifurcated labour market made up of a primary segment that produces relatively stable, skills-oriented jobs with higher pay and benefits, and a secondary segment of unskilled, temporary and low-pay jobs, with significant mobility barriers between the segments (e.g. Piore, 1979; Taubman and Wachter, 1986). With the hukou system acting as a form of internal passport control, China's huge geographical extent and intra-Han cultural and linguistic diversities also create some resemblance to international migration, which intensifies social segmentation (Honig, 1990).

As in most developing economies, migration in China in peaceful times is primarily employment or labour-driven, whether initiated by the government or by individuals. As the hukou system defines different opportunities and constraints for people of different hukou statuses and causes significant socioeconomic segmentation, one can conceive of a system of two different large 'circuits' within which migration operates. While most migration responds to universal factors such as distance and employment to varying degrees, migrants within each circuit function quite differently, depending on the condition of the origin area (such as high population pressure), its available resources (mainly job information and opportunities) and constraints they have to face (such as transportation costs and administrative barriers). Typically, Chinese peasant migrants (the main part of non-hukou migration) depend heavily on informal migration networks (see Solinger, 1995c), moving from regions of high population pressure to places where large numbers of low-skilled jobs are available. The movements have mostly been self-initiated (ziliu) responses by peasants to market forces of demand and supply within 
the confines permissible by the current political and social structures. Hukou migration, however, generally does not respond directly to job opportunities in the low-skill sector. Rather, mobility occurs mostly through various government channels, such as the job assignment system for college graduates and demobilised military personnel, the job transfer system for state workers (even because of personal reasons), and return migration as the government repudiates various policies such as rustication. These moves generally require official approval in accordance with government policies and labour plans through a set of complicated bureaucratic procedures.

Our formulation treats migration as a form of investment for the migrant to maximise benefits in a broad sense (including nonpecuniary benefits such as amenities) (Lewis, 1954; Sjaastad, 1962; Harris and Todaro, 1970; Todaro, 1976). The relevance of this behavioural assumption rests on the fact that most, if not all, migration in the post-Mao era is arguably 'voluntary' migration. It is true that hukou labour migration is mostly initiated by the state in accordance with national and regional economic and labour force plans, and, in the extreme case, people are treated merely as one of the inputs of production and are subject to the disposal of the planner (Ma, 1995). In practice, in the last two decades there has been a high degree of concurrence between individuals' wishes and state assignments in most cases. Some of the moves were initiated by the state, but many by individuals, although still regulated by Government's labour plans of various kinds. Migration, most obviously nonhukou migration, then operates similarly to 'free' migration in market economies, subject to administrative and economic constraints, which are numerous and quite powerful at times in China. Hare's $(1998,1999)$ work has provided some good illustrations of this type of migration in China. The similar fortunes of most non-hukou migrants in China and Third World immigrants to developed countries (both legal and illegal) further suggest some consistency in the mechanisms and processes of migration (Roberts, 1997). In a general sense, different types of migration react differently and to different situations in the origins and destinations, and are conditioned by a number of other factors, as Gurak and Caces (1992) have outlined in a different context.

\section{EMPIRICAL STUDY}

The data-set employed is the interprovincial migration (IPM) subsample of the $1 \%$ systematic migrant sample of the 1990 Census, which contains 353,517 individual records with 16 variables, including basic demographic variables, hukou type and status, three migration variables (origin, type of origin place, and reason for migration), educational and occupational variables (see State Council and SSB, 1993). Our main analysis is to link migration with contextual factors, i.e. conditions at both origin and destination. This is only feasible at the interprovincial level, as the 1990 Census recorded only the provinces from which migrants originated. IPM accounts for 32.5\% of all the migration in 1985-90 as defined by the 1990 Census.

Our IPM subsample contains a total of 116,924 records of migrants, accounting for $33.1 \%$ of the migrant sample (see Table 2). In the following, we will approach the two types of migration from three complementary angles. We first compare the socioeconomic characteristics of the two major types of migrants, hukou and non-hukou. Because labour migration is the core of non-hukou migration, and because of their volume (more than half of all non-hukou migrants) and behaviours, we have also concentrated on 'non-hukou labour migration'. For clarity, these migrants will hereafter be referred to as 'rural labour migrants' and be treated separately. Labour migration has also been a major strategy used by rural households to improve their living standards. The descriptive comparison is followed by a more focused study of the interprovincial migration flows of the two types (and relevant subtypes) using maps. Finally, we set up place-to-place migration models to analyse the relationship between migration rates and a set of independent variables relating destinations and origins.

\section{Descriptive Analysis}

Socioeconomic characteristics of migrants

In the 1990 Census, migrants were defined as 
Table 2. Social and demographic characteristics of interprovincial migrants, 1985-1990 (\%).

\begin{tabular}{|c|c|c|c|c|c|c|}
\hline \multirow[b]{2}{*}{ Migrant characteristic } & \multicolumn{3}{|c|}{ All migration } & \multicolumn{3}{|c|}{ Interprovincial migration } \\
\hline & Total & Hukou & Non-hukou & Hukou & Non-hukou & Rural labour \\
\hline \multicolumn{7}{|l|}{ Sex } \\
\hline Male & 56.1 & 55.3 & 57.3 & 56.3 & 61.3 & 77.2 \\
\hline Female & 43.9 & 44.7 & 42.7 & 43.7 & 38.7 & 22.8 \\
\hline \multicolumn{7}{|l|}{ Age (years) } \\
\hline $5-14$ & 8.2 & 7.7 & 8.5 & 9.1 & 7.2 & \\
\hline $15-19$ & 13.4 & 13.7 & 13.0 & 10.9 & 13.1 & 15.9 \\
\hline $20-29$ & 51.8 & 54.8 & 48.0 & 52.3 & 50.9 & 57.2 \\
\hline $30-39$ & 13.0 & 11.4 & 14.9 & 13.3 & 14.8 & 16.6 \\
\hline $40-49$ & 6.6 & 6.6 & 6.6 & 8.0 & 6.3 & 6.5 \\
\hline $50-59$ & 3.8 & 36.0 & 4.0 & 4.0 & 3.5 & 2.7 \\
\hline$>60$ & 3.3 & 2.2 & 4.7 & 2.6 & 4.1 & 1.1 \\
\hline \multicolumn{7}{|l|}{ Marital status } \\
\hline Unmarried & 40.9 & 44.0 & 37.4 & 38.5 & 38.6 & 52.9 \\
\hline Married & 48.2 & 46.3 & 50.5 & 50.4 & 50.8 & 46.0 \\
\hline \multicolumn{7}{|l|}{ Regular residence } \\
\hline City & 19.5 & 28.2 & 9.2 & 43.0 & 11.6 & 4.5 \\
\hline Town & 18.9 & 23.7 & 13.2 & 17.4 & 10.5 & 8.7 \\
\hline Rural township & 61.6 & 48.2 & 77.6 & 39.5 & 77.9 & 86.8 \\
\hline \multicolumn{7}{|l|}{ Reasons for move } \\
\hline Job transfer & 11.9 & 18.0 & 4.6 & 24.1 & 5.2 & \\
\hline Job assignment & 6.9 & 10.4 & 2.7 & 11.7 & 0.8 & \\
\hline Employment in industry and business & 23.7 & 1.8 & 50.3 & 1.7 & 54.7 & 100.0 \\
\hline Studying or training & 12.8 & 21.4 & 2.8 & 14.8 & 2.2 & \\
\hline Living with relatives and friends & 9.7 & 6.6 & 13.2 & 8.7 & 12.7 & \\
\hline Retirement or resignation & 1.6 & 2.1 & 1.0 & 2.5 & 0.8 & \\
\hline Migration with families & 11.0 & 13.7 & 7.9 & 15.6 & 7.4 & \\
\hline Marriage & 13.8 & 15.6 & 11.3 & 14.8 & 11.4 & \\
\hline Other & 8.7 & 10.4 & 6.3 & 6.2 & 4.8 & \\
\hline \multicolumn{7}{|l|}{ Education } \\
\hline No schooling & 9.0 & 6.1 & 12.3 & 6.2 & 12.0 & 6.1 \\
\hline Elementary school & 25.3 & 20.5 & 30.8 & 20.7 & 31.7 & 29.4 \\
\hline Junior high school & 34.0 & 26.3 & 43.2 & 26.5 & 43.8 & 54.7 \\
\hline Senior high school & 11.7 & 13.6 & 9.6 & 14.4 & 8.8 & 8.8 \\
\hline College & 20.1 & 33.5 & 2.1 & 32.3 & 3.7 & 0.9 \\
\hline Not in the workforce & 36.8 & 45.2 & 26.6 & 38.6 & 22.6 & 0.6 \\
\hline \multicolumn{7}{|l|}{ Occupational status of those in workforce } \\
\hline Professional & 11.7 & 21.0 & 3.3 & 23.6 & 2.7 & 1.4 \\
\hline Administrative & 2.2 & 3.6 & 1.2 & 4.1 & 0.9 & 0.8 \\
\hline Clerical & 4.6 & 7.8 & 1.5 & 11.1 & 1.2 & 0.8 \\
\hline Sales & 7.3 & 4.2 & 10.4 & 4.2 & 9.0 & 11.5 \\
\hline Service & 7.0 & 4.6 & 9.7 & 4.4 & 7.8 & 8.6 \\
\hline Industrial workers & 41.9 & 26.8 & 55.9 & 24.4 & 59.3 & 70.5 \\
\hline Farmers & 25.3 & 31.9 & 18.4 & 28.3 & 18.9 & 6.6 \\
\hline$n$ & 353,517 & 190,599 & 159,320 & 54,104 & 62,820 & 34,233 \\
\hline
\end{tabular}

Source: 1990 Census 1\% Sample. 
those aged five years and above who had a different place of regular residence on 1 July 1985. For those who did not have a local hukou in the destination (non-hukou migrants), they would have to be in the destination for at least one year, or to be away from their place of registration for at least one year (State Council and SSB, 1993). This operational definition of migrant therefore excludes short-distance, intra-county/city migrants and non-hukou migrants who moved between mid-1989 and mid-1990. By this, it would also exclude all the short-term 'floating population', a good portion of whom are not truly migrants (such as visitors, tourists, and people on business trips) (see Chan, 1994; Solinger, 1995a).

Table 2 summarises the socioeconomic characteristics of three types of interprovincial migrants, hukou, non-hukou and rural labour migrants. Information about the characteristics of all hukou and non-hukou migrants (including within-province migrants) is also supplied to provide the context. Overall, as the statistics show, there are broad similarities in many aspects of the interprovincial (IP) migrants to all migrants. Because of this, it is likely that many of the processes of IPM examined in this paper would also exist for migration within provinces. For the purposes of this paper, however, we are more interested in comparing hukou and non-hukou migrants. Generally, hukou and non-hukou migrants were dominated by males and those aged 20-29. This is the age cohort most likely to generate life-cycle events related to residential changes, just like migrants in many other countries (Skeldon, 1990). Non-hukou migrants had a higher sex ratio and this was even higher in the IP migrants. This became very pronounced in rural labour migration (last column) where males outnumbered females by a ratio of 3 to 1 .

The broad similarities between the two types end when one moves to the socioeconomic variables. While non-hukou migrants (and rural labour migrants) are heavily concentrated in the educational levels of junior middle and primary school, hukou migrants are disproportionately represented in the highly educated categories (senior middle school level and up). In fact, in the hukou migrant population, the college-educated had the largest share (about a third) among the four educational attainment levels (this compares with less than $2 \%$ of the nation's population aged six and over having had college-level education in 1990). This clearly attests to the high skill selectivity of hukou migration.

Non-hukou migrants had a higher percentage (about three-quarters) in the workforce than the hukou migrants. IP migrants had also higher employment rates, and therefore made predominantly work-related moves. Among those in the workforce, it is clear that hukou migrants (predominantly moving to urban destinations, except for marriage migration) are highly skewed in the professional and technical categories (about 21-24\%). Their composition broadly resembles that of the urban population as a whole (Chan, 1999). In contrast, $95 \%$ of the non-hukou migrants had employment at the clerical level or lower. Common jobs were manufacturing frontline workers, construction workers, nannies, and sales and service workers (Yang, 1994). There were also many self-employed craft-type workers (artisans) and small vendors. In fact, self-employment has become a more favoured sector for rural migrants for good reasons (see local studies such as Li and Siu, 1997; Wang and Zuo, 1997). The large numbers of farm workers in hukou migration largely reflect rural-rural marriage migration of women (see Fan and Huang, 1998).

One more striking difference between hukou and non-hukou migrants is in the type of regular residence at the origin. In the IP migrant sample, about $60 \%$ of hukou migrants came from urban areas, mostly from cities; in fact, most IP hukou migration occurred within the urban sector itself. On the other hand, 78\% of non-hukou migration was from the countryside (rural townships), and an even higher percentage $(87 \%)$ was found for rural labour migration. Essentially, non-hukou migration originates from the countryside and it includes a large amount of rural-to-urban migration.

Labour migration ${ }^{3}$ accounts for about 50$60 \%$ of both types of IP migration, similar to other developing countries. The channels of migration, however, are different between the two and from those in other countries. 'Job transfer', 'job assignment upon graduation', and 'study and training' in China refer to employment allotment or employment-or- 

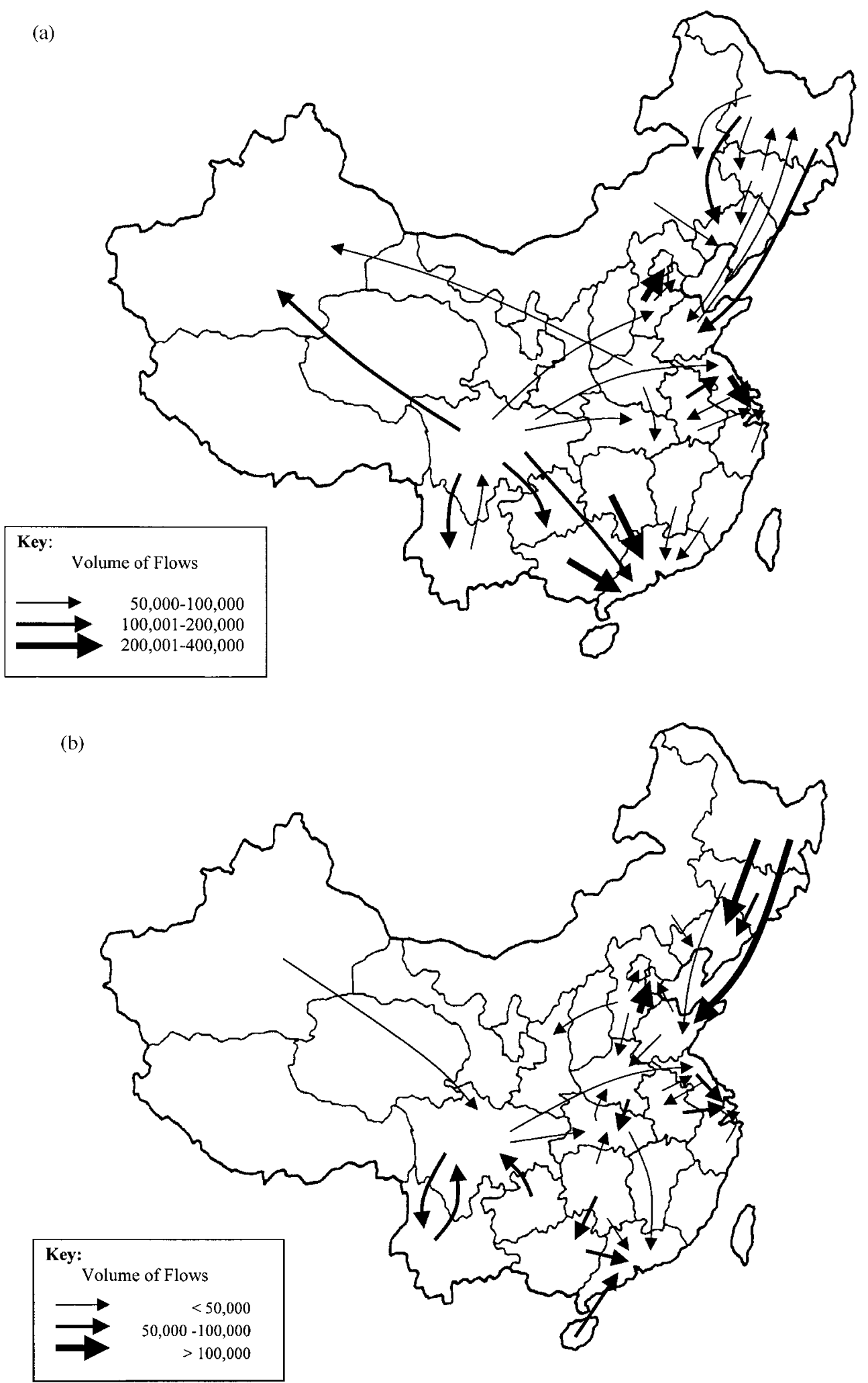

Figure 1(a,b). The 30 largest interprovincial flows in 1985-90. (a) All migrants. (b) Hukou migrants. Source: 1990 Census data and 1\% sample. 


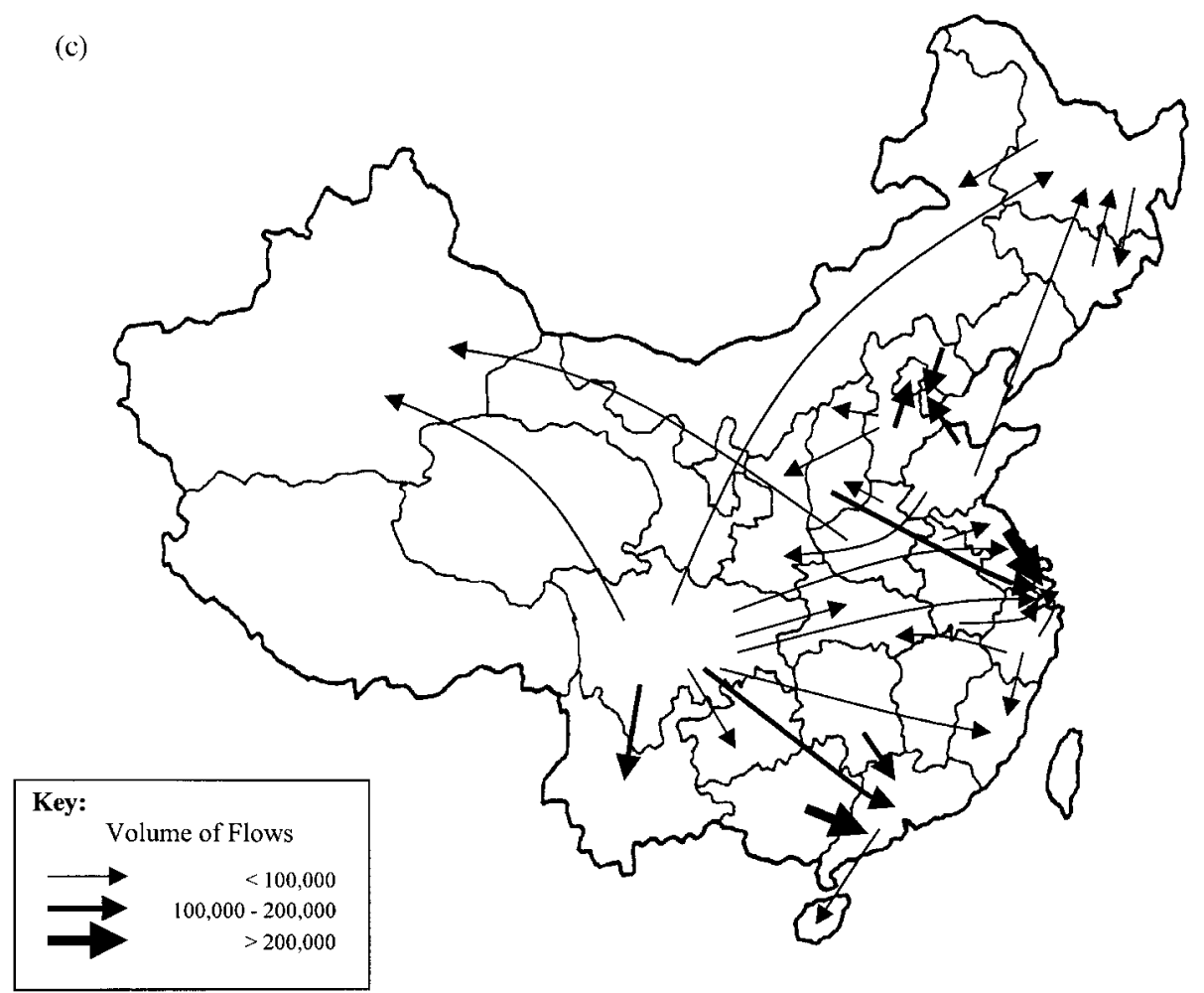

Figure 1(c). The 30 largest interprovincial flows in 1985-90 (Non-Hukou migrants). Source: 1990 Census data and $1 \%$ sample.

iented training controlled almost exclusively by the government. These were the channels through which practically all hukou labour migrants got or changed their jobs and moved. By contrast, of those non-hukou migrants citing a job as the reason for migration, close to $90 \%$ found jobs and moved using market channels (the 'employment in industry and business' category refers to self-sought jobs outside the plan sector), typically through the help of relatives and friends, job ads, or recruitment agents. Only a tiny proportion (about $12 \%$ of those job-related migrants) cited government job channels as reasons for migration.

\section{Interprovincial migratory flows}

The second part of the analysis is to examine the major flows of the various types of IP migration and to place our study in the context of China's geography. Because of the graphic and space limitations, we can only show about 30-40 flow streams, instead of all flows (ranging from 512 to 755 depending on the type), on each map. The flow maps therefore display just the largest flows of migration streams in each type, with varying proportions of the number of migrants in each type (examined later).

Figure 1a depicts the 30 largest non-differentiated migration streams crossing provincial boundaries. These 30 streams represent about $40 \%$ of the total IP migrants. Generally, interprovincial flows were primarily towards the coast. Most of the coastal provinces (such as Guangdong, Beijing, Shanghai and Jiangsu) gained population from provinces like Sichuan and Guangxi in Central and Western China. ${ }^{5}$ Many believe that this reflects the differences in the level of economic development. While this may be true, this amalgam also masks significant differences between hukou migration and non-hukou migration and related complexities. Figures $1 b$ and $1 c$ reveal the different patterns of the two types of migration. Non-hukou flows (Fig. 1c), mostly for jobs, are predominantly from the interior to the 
K. W. Chan et al.
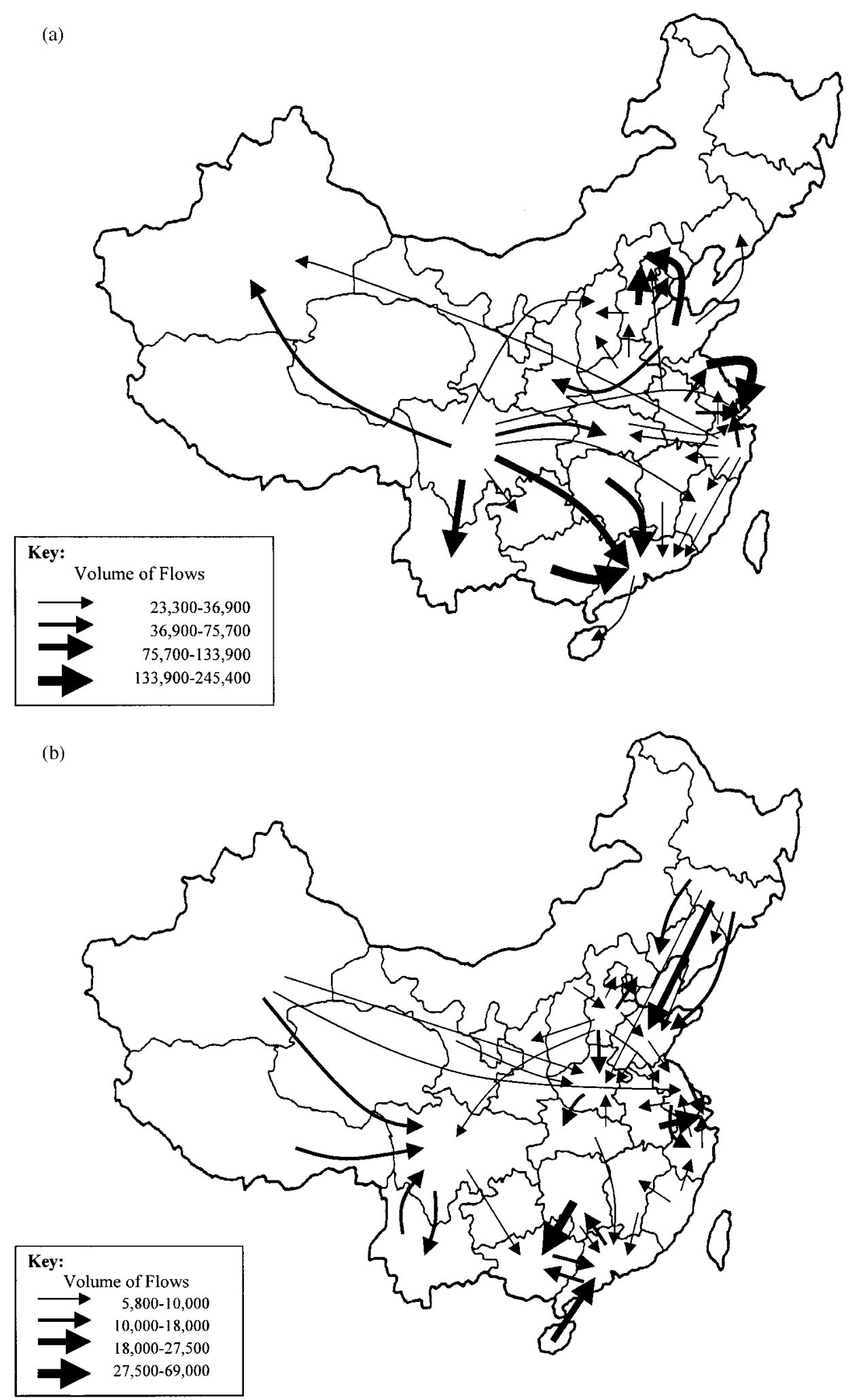

Figure 2. The largest interprovincial flows, 1985-90. (a) Non-hukou 'Employment in industry and business' group. (b) Hukou 'job transfers' group. Source: 1990 Census 1\% sample. 


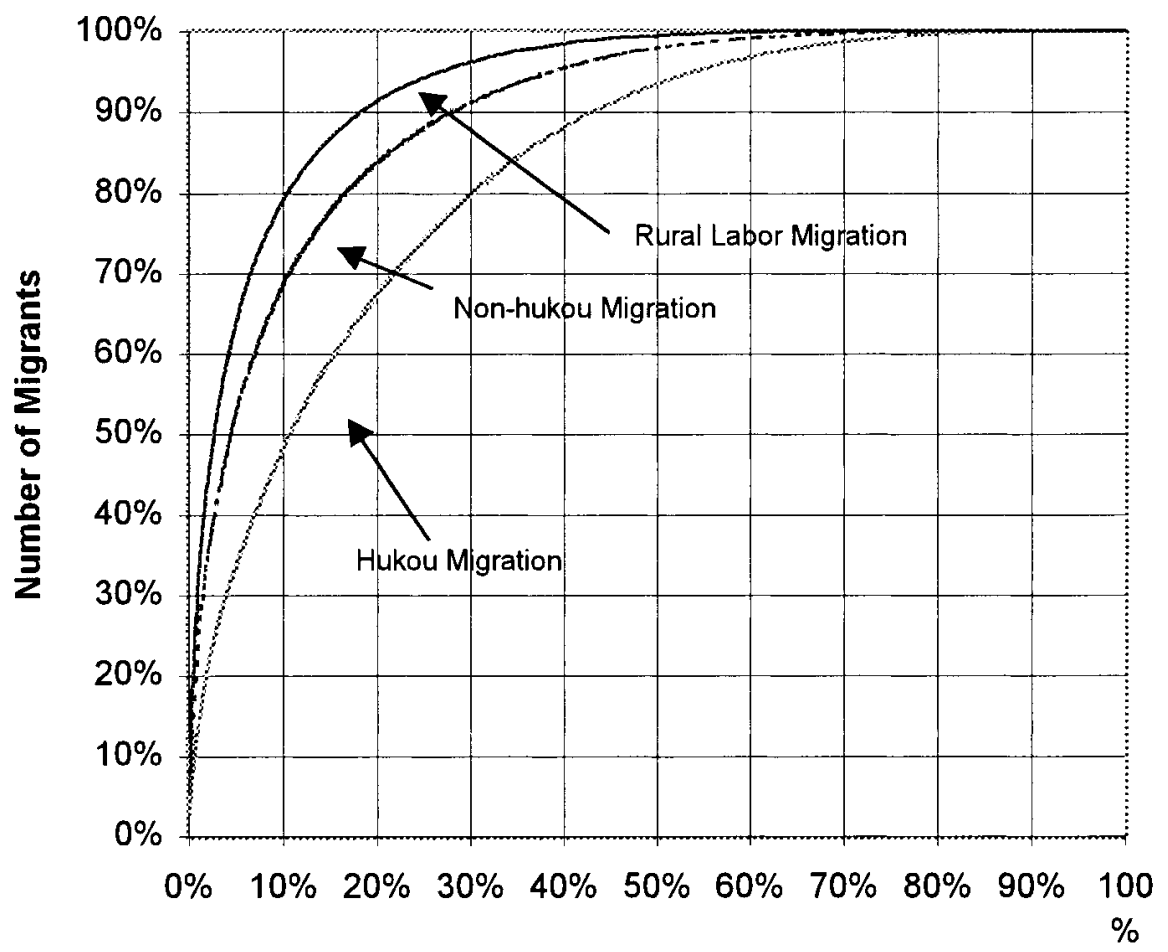

Number of Streams

Figure 3. Distribution of migration streams. Source: 1990 Census 1\% sample.

coast, converging at major economic hubs like the Pearl River Delta (Guangdong) and metropolises such as Shanghai and Beijing. There were also a considerable number of migrants from the densely populated Sichuan and Henan areas to frontier provinces like Xinjiang and Nei Mongol, mostly taking up jobs or business opportunities there in commerce, construction and farming. Overall, the nonhukou migrants moved to where job opportunities were available. This is evidence of market forces at work. It appears that these forces were so powerful that in some cases, a significant number of migrants were willing to cross hundreds, if not thousands, of kilometres to very distant, and often culturally and environmentally different provinces (such as from Sichuan to Guangdong and Heilongjiang), although many (the largest two streams) moved to neighbouring provinces. These migrants expected to benefit from large wage differentials (often in the range of 3-4 times more) between an urban unskilled job in a coastal city and a farm job in an inland province (see Liu, 1995).
However, for many hukou migrants, such large economic gains did not exist. Except for return migratory streams like those coming from Xinjiang and Heilongjiang, most out-ofprovince hukou migratory streams were generally quite 'conservative', over shorter distances than the non-hukou migrations (Fig. 1b). They appear to have preferred nearby provinces whose culture, languages and environment were likely to be similar and presumably easier to adapt to (see also Ding, 1994). Another characteristic of hukou migratory streams at the upper end is the prevalence of two-way flows for some provinces. There were significant exchanges between many pairs of adjacent provinces, both of similar (e.g. Sichuan and Yunnan) and different (e.g. Jiangsu and Anhui) economic levels. The situation is different for non-hukou migration. Provinces active in migration were either major net importers (such as Guangdong and Shanghai) or major net exporters (such as Sichuan). The largest flows were from those provinces with very large populations.

Looking at the above three maps together 
and supplemented by information in the origin-destination (OD) matrices, we can see that the three provincial-level cities, Beijing, Shanghai and Tianjin, and Guangdong, are major destinations for both hukou and nonhukou migrants. For non-hukou migration, many large flows were from provinces with larger populations (also much higher population densities), such as Sichuan, Henan, Shandong, Zhejiang and Jiangsu. It is likely that the push factor of population pressure was a significant one for non-hukou migration. For hukou migration, the basic pattern is that, in addition to moving to the popular areas described above, migrants moved away from the frontier provinces, such as Heilongjiang and Xinjiang, to coastal provinces such as Jiangsu and Shandong. The latter group comprised return migrants who moved to frontier regions in the 1950s to 1970s. ${ }^{6}$ The above patterns can be further illustrated by looking at the employment-generated hukou and non-hukou migrations only, in Figs 2a and $2 \mathrm{~b}$. Figure $2 \mathrm{a}$ shows only the 'rural labour' migration flows ('employment in business and industry' group) of Fig. 1c. It is clear that a few destinations and origins dominate the whole scene. Indeed, the largest 30 flows (about $4 \%$ of the total number of flows) accounted for about $58 \%$ of all the rural labour migrants, compared with $45 \%$ for all non-hukou migration and only $29 \%$ for hukou migration (see Fig. 3). Three national labour markets (i.e. Beijing-Tianjin, Shanghai-Jiangsu and Guangdong) stand out, with most migrants supplied by a few populous provinces: Sichuan, Zhejiang, Shandong, Jiangsu and Hebei. The largest migratory flows of the hukou 'job transfers' group in Fig. 2b illustrate a different pattern: there were a few significant long-distance return flows from the frontiers to the coast, and many, perhaps regular, IP migration flows operating largely over short distances between nearby provinces.

\section{Statistical Analysis}

The above flow maps provide a background analysis of the geographical patterns of the major types of migrants. To go beyond the descriptive accounts and gain some understanding of the general factors that determine
IP migration of various types, we have set up a statistical model that links migration with the geographical and economic conditions in both origins and destinations. This is different from previous studies that focused only on either the destination or the origin. Such an approach also allows us to make generalisations about the two types of migrants and the migration circuits within which they function. A number of migration models (in-migration or outmigration) used in recent work implicitly assume that potential migrants have equal access to destinations in terms of information and transportation, and that destination attributes do not vary across origins (Liang and White, 1997). Thus, estimates from those models may overestimate the responsiveness of migrants to destination factors in a spaceless context, and neglect the relative impacts of either origin or destination factors (see also Mueller, 1982). Place-to-place migration models can overcome those deficiencies and put the analysis in a solid geographical context. The models link the gross migration rate between origins and destinations to an array of factors, such as demographic, socioeconomic variables at origins and destinations, and distance. This type of model has been widely applied in market economies, in both developed and developing countries, where migrants can 'freely' respond to existing opportunities and constraints (Rogers, 1967; Greenwood, 1969; Wadycki, 1974; Fields, 1982; Schultz, 1982). Our design is to assess the impact of a number of variables on the migration rates through a set of ordinary least square (OLS) regression models. Using the same variables, we will conduct regression analyses for different types of migration, and by comparing the regression coefficients, we can determine the degree of sensitivity of each factor on each type of migration.

A place-to-place migration model commonly takes the double logarithmic form as follows:

$$
\begin{gathered}
\ln m_{i j}=\alpha+\beta_{1} \ln P_{\mathrm{i}}+\beta_{2} \ln P_{\mathrm{j}}+\Sigma \gamma_{\mathrm{m}} \ln X_{\mathrm{mi}} \\
+\Sigma \lambda_{\mathrm{n}} \ln X_{\mathrm{nj}}+\delta \ln D_{\mathrm{ij}}+\mathrm{e}_{\mathrm{ij}}
\end{gathered}
$$

where $m_{\mathrm{ij}}$ is the gross migration rate from region $i$ to region $j, P_{\mathrm{i}}$ and $P_{\mathrm{j}}$ are the populations in region $i$ and region $j, X_{\mathrm{mi}}$ and 
Table 3. Definitions of variables in the migration models.

\begin{tabular}{|c|c|c|}
\hline Variables & Notations & Definitions \\
\hline Gross migration rate & $M_{\mathrm{ij}}$ & $\begin{array}{l}\text { The number of migrants in each type moving from province i to } \\
\text { province } \mathrm{j} \text { in 1985-90 over the population in province i in 1985.* }\end{array}$ \\
\hline Distance & $D_{\mathrm{ij}}$ & $\begin{array}{l}\text { The railway distance in kilometres between the provincial } \\
\text { capitals of province } i \text { and province } j\end{array}$ \\
\hline Population & $P_{\mathrm{i}}, P_{\mathrm{j}}$ & The size of population at $i$ and $j$, respectively, in 1985 \\
\hline Consumption per capita & $C_{\mathrm{i},} C_{\mathrm{j}}$ & $\begin{array}{l}\text { The consumption level per capita in provinces } \mathrm{i} \text { and } \mathrm{j} \text { respectively, } \\
\text { in } 1985\end{array}$ \\
\hline Agricultural share & $A_{\mathrm{i}}, A_{\mathrm{j}}$ & $\begin{array}{l}\text { The percentage of agricultural labour in the total labour force for } \\
\mathrm{i} \text { and } \mathrm{j} \text { in } 1985\end{array}$ \\
\hline Migration stock & $M S_{\mathrm{j}}$ & $\begin{array}{l}\text { The number of migrants in each type in 1982-86 over the total } \\
\text { population of province } \mathrm{j} \text { in } 1985 \text {. }\end{array}$ \\
\hline Foreign direct investment & $F D I_{\mathrm{j}}$ & $\begin{array}{l}\text { The absolute amount of direct foreign investment in province } \\
\text { j in } 1985\end{array}$ \\
\hline Land-labour ratio & $L L_{\mathrm{i}}, L L_{\mathrm{j}}$ & $\begin{array}{l}\text { The ratio of arable land and the size of the agricultural labour } \\
\text { force at } i \text { and } j \text { in } 1985\end{array}$ \\
\hline
\end{tabular}

$X_{\text {nj }}$ are the socioeconomic variables in region $\mathrm{i}$ and region $\mathrm{j}, D_{\mathrm{ij}}$ is the distance between $\mathrm{i}$ and $\mathrm{j}$, and $e_{i j}$ is the error term. It is easy to see the similarity of the model to the 'gravity' model. ${ }^{7}$ The double logarithmic form is preferred for two reasons: (a) it has behaviour implications and is comparable to the logistic model; ${ }^{8}$ (b) a double $\log$ function allows an assessment of the sensitivity of independent variables on dependent variables (as it measures the percentage change). In addition to 'gravity' variables (i.e. populations at origins and destinations and the distance between them), other variables such as income, unemployment or employment, past migration, and amenities are often included in the model (see Mueller, 1982, for details). Two widely used variables are wage rate and unemployment rate, mostly because of the famous Harris-Todaro expected wage hypothesis. Migrants respond not just to simple wage rate or employment rates, but the expected wage rate, which is the product of the current wage rate and the probability of finding a job.

One advantage of the place-to-place migration model is that it can examine the relative importance of push factors at origins and pull factors at destinations. Past studies have found that impacts of economic conditions at origins and destinations are not symmetrical, and generally the pull factors at destinations have stronger impacts (Lowry, 1966; Fields, 1982). This is contrary to expectations that origin factors should be more important, ceteris paribus, because migrants have more information about origin conditions. The oft-cited explanations for this asymmetry are migration finance and selectivity of migrants (Greenwood, 1975; Mueller, 1982). An increase of income at the origin may decrease the incentive to migrate, but it can also increase the possibility of migration as an effective alter- 
native, especially for those who would like to migrate but could not afford to migrate previously. So the two impacts of income increase on migration may offset each other, leaving the origin income insignificant. Another argument is that migrants more likely affected by origin conditions have already moved out, so high unemployment rates in depressed areas are not associated with high out-migration rates.

\section{An empirical model for Chinese migration}

To suit the Chinese situations, a formal model to test the determinants of regional migration is revised. In addition to the classical variables such as distance and population, we have also included variables relevant or specific to China:

$$
\begin{array}{r}
M_{\mathrm{ij}}=\mathrm{f}\left(D_{\mathrm{ij}}, P_{\mathrm{i}}, P_{\mathrm{j}}, A_{\mathrm{i}}, A_{\mathrm{j}}, C_{\mathrm{i}}, C_{\mathrm{j}},\right. \\
\left.M S_{\mathrm{j}}, F D I_{\mathrm{j}}, L L_{\mathrm{i}}, L L_{\mathrm{j}}\right)
\end{array}
$$

Definitions of the variables are given in Table 3. Below are some additional explanations. We use railway distance to represent distance, $D_{\mathrm{ij}}$, since it is the dominant means of long-distance passenger transportation in China (unlike the linear distance used in Wang, 1993; Li, S. 1994). Although direct transportation costs for migrants may be quite small compared with the earnings, they are still consistently found to be the most important factors in gross migration in both developed and developing countries (Greenwood, 1975; Schultz, 1982; Yan, 1998). Increase in distance not only raises the transportation costs but also increases the uncertainty and risks of migration, because information about more distant places is generally less readily available. Also, the further away from family and friends, the more one endures psychic costs because of the greater difficulty in contacting home and the greater adaptation required to the new environment (Greenwood, 1975).

In China, usable unemployment rates (rural or urban) are not available for our purpose (Banister and Taylor, 1990; Jefferson and Rawski, 1992). We choose instead the percentage of agricultural labour in the total labour force $\left(A_{\mathrm{i}}\right.$ and $\left.A_{\mathrm{j}}\right)$ as a proxy for population pressure and the economic structure of the province. The variable reflects mostly the situation of unemployment and underemployment in rural areas. Generally, higher percentages of the labour force in agriculture correlates with higher percentages of surplus labour. The indicator is also used as the variable to measure the degree of industrialisation (Kuznets, 1982; Nielsen, 1994). We expect high and positive coefficients of $A_{\mathrm{i}}$ for non-hukou migration and rural labour migration, but a lower coefficient for hukou migration, and a negative coefficient of $A_{\mathrm{j}}$ for both hukou and non-hukou migration.

Neither are Chinese wage data reflective of the total incomes, since non-wage incomes are significant in China (Solinger, 1995b; Jefferson and Rawski, 1992). Other indices, such as industrial output per capita or GDP per capita, have no behavioural meaning, although they are related to economic development. After some experimentation, we have chosen per capita consumption at the provincial level as a proxy for wage or living standard. For both non-hukou and hukou migrants, generally we expect migration rate to correlate negatively with consumption at the origin, and positively with that at the destination. But as previously stated, higher incomes (as measured by consumption) may also increase the ability to finance migration, and thus might be positively associated with migration, especially in the early stages. For hukou migration, as there was increasing concurrence between government plans and individual choice due to greater autonomy of enterprise in labour assignment and to greater government investment in the coastal areas, one would also expect hukou migration to be attracted to higher-income locations from lower-income provinces.

Populations at origins and destinations $\left(P_{\mathrm{i}}\right.$ and $P_{\mathrm{j}}$ ) are typical gravity variables in migration models. Generally, population size is used as a kind of proxy variable to economic opportunities caused by agglomeration economies, so people will move from less populated to more populated places. For example, a larger population would have a greater demand for basic services, which are typically provided by informal sectors in developing countries. Greenwood (1971) proposed that migration would be positively associated with destination population size, and negatively 
Table 4. Place-to-place migration double logarithmic regression models: weighted by $\%$ of migrants of each stream.

\begin{tabular}{|c|c|c|c|c|}
\hline & & Migr & types & \\
\hline & Hukou & Non-hukou & Rural labour & All \\
\hline Distance from $\mathrm{i}$ to $\mathrm{j}\left(D_{\mathrm{ij}}\right)$ & $\begin{array}{l}-0.802^{* *} \\
-18.3\end{array}$ & $\begin{array}{l}-0.712^{* *} \\
-11.9\end{array}$ & $\begin{array}{l}-0.905^{* *} \\
-13.5\end{array}$ & $\begin{array}{l}-0.749^{* *} \\
-15.7\end{array}$ \\
\hline Origin population $\left(P_{\mathrm{i}}\right)$ & $\begin{array}{l}-0.607^{* *} \\
-11.1\end{array}$ & $\begin{array}{l}-0.177 \\
-1.8\end{array}$ & $\begin{array}{l}-0.406^{* *} \\
-3.4\end{array}$ & $\begin{array}{l}-0.308^{* *} \\
-4.5\end{array}$ \\
\hline Agricultural share at $\mathrm{i}\left(A_{\mathrm{i}}\right)$ & $\begin{array}{l}0.500^{* *} \\
4.7\end{array}$ & $\begin{array}{l}0.925^{* *} \\
4.1\end{array}$ & $\begin{array}{l}2.014^{* *} \\
7.1\end{array}$ & $\begin{array}{l}0.731^{* *} \\
5.11\end{array}$ \\
\hline Migration stock $\left(M_{\mathrm{j}}\right)$ & $\begin{array}{l}-0.071 \\
-1.9\end{array}$ & $\begin{array}{l}0.193^{* *} \\
3.1\end{array}$ & $\begin{array}{l}0.235^{\star *} \\
6.2\end{array}$ & $\begin{array}{l}0.075 \\
1.5\end{array}$ \\
\hline Foreign direct investment $\left(F D I_{j}\right)$ & $\begin{array}{l}0.195^{\star *} \\
7.5\end{array}$ & $\begin{array}{l}0.366^{* *} \\
12.6\end{array}$ & $\begin{array}{l}0.330^{* *} \\
11.3\end{array}$ & $\begin{array}{l}0.325^{* *} \\
12.6\end{array}$ \\
\hline Land/labour ratio at $\mathrm{i}\left(L L_{\mathrm{i}}\right)$ & $\begin{array}{l}0.759^{* *} \\
12.3\end{array}$ & $\begin{array}{l}-0.100 \\
-0.8\end{array}$ & $\begin{array}{l}-1.437^{* *} \\
-8.7\end{array}$ & $\begin{array}{l}0.392^{\star *} \\
5.1\end{array}$ \\
\hline Land/labour ratio at $\mathrm{j}\left(L L_{\mathrm{j}}\right)$ & $\begin{array}{l}-0.367^{* *} \\
-3.2\end{array}$ & $\begin{array}{l}0.585^{* *} \\
5.1\end{array}$ & $\begin{array}{l}0.445^{* *} \\
3.2\end{array}$ & $\begin{array}{l}0.36^{* *} \\
3.5\end{array}$ \\
\hline Intercept & $\begin{array}{l}11.122^{* *} \\
16.4\end{array}$ & $\begin{array}{l}6.057^{* *} \\
5.6\end{array}$ & $\begin{array}{l}12.235^{* *} \\
9.2\end{array}$ & $\begin{array}{l}7.777^{* *} \\
10\end{array}$ \\
\hline $\begin{array}{l}R^{2} \\
F \\
\text { Number of cases }\end{array}$ & $\begin{array}{l}0.49 \\
100^{* *} \\
755\end{array}$ & $\begin{array}{l}0.38 \\
57^{* *} \\
660\end{array}$ & $\begin{array}{l}0.53 \\
83^{* *} \\
512\end{array}$ & $\begin{array}{l}0.43 \\
77^{* *} \\
732\end{array}$ \\
\hline
\end{tabular}

Note:

** Significant at 0.01 level.

$t$-values are in italics.

with origin population size. Schultz (1982) argued that the population variable could reflect the impacts of other socioeconomic factors that influence migration and which are not specified in the models, and thus not giving purely the effect of population size. Population size at the destination should have positive effect for both non-hukou and hukou migration. Large population size at the origin is also positively correlated with rural population surplus; therefore, it would be a push factor for non-hukou migration (positively correlated) but we do not expect hukou migration to be associated with that variable.

Migration networks, represented by migration stock (MS), which has been found to be a significant variable in migration models based on other countries (Greenwood, 1969; Navril, 1977; Hatton and Williamson, 1994), are also very important to migration in China (Rozelle et al., 1997; Yan, 1998). Since migration is often facilitated by friends and relatives at the destination by reducing risks and providing information and accommodation, it reflects the effects of social networks. So typically the migration stock variable should be positive. There are probably different ways and degrees of 'networking' with previous migrants for hukou and non-hukou migrants. Since nonhukou migrants in China rely heavily on informal networks, we expect the migration stock to be a much more important variable than for hukou migrants.

Another variable that is important in deter- 
mining migration in present China is foreign direct investment (FDI). Foreign investment has been studied in terms of its impact on international migration, but much less for internal migration (Ricketts, 1987; Sassen, 1988). Recent studies and migrant surveys in China have found that migrants, especially rural labour migrants, are attracted to areas where foreigninvested firms are concentrated, such as the Zhujiang Delta (e.g. Fan, 1996). The 1980s was a period of rapid employment growth in the foreign-invested enterprise sector, in contrast to the relatively sluggish expansion of the stateowned sector. Most foreign ventures in China are in labour-intensive sectors, employing large numbers of both skilled and especially unskilled workers.

In order to capture the uneven distribution of land resources and labour force, we have also included land-labour ratios at the origin and destination, respectively $\left(L L_{\mathrm{i}}\right.$ and $\left.L L_{\mathrm{j}}\right)$. The land-labour ratio measures how much arable land is available per agricultural worker, and so it is a direct measure of the availability of land resources and surplus rural labour. Frontier provinces, such as Heilongjiang and Xinjing, have favourable land-labour ratios. We expect the land-labour ratio at the origin to correlate negatively with non-hukou migration, since this type of migrant is more likely to come from provinces with low land-labour ratios. Non-hukou migrants moved to areas with high land-labour ratios for employment in the agricultural sector. In contrast, hukou migrants are unlikely to go to areas with high land-labour ratios in the reform period.

As far as the distribution of migration streams is concerned, an examination of migration OD matrices or even the flow maps showing only the largest flows (Figs 1 and 2) reveals it to be highly uneven. A great majority of migrants were concentrated in just a few of the largest streams. The degree of concentration also varies from one type to another, as illustrated by Fig. 3. Given the huge differences in size between the largest migration streams and the smallest (a multiple of several hundred times), we cannot treat every migration stream as equal. Instead, we have chosen the weighted regression model to estimate the coefficients. The weight for a migration stream is the percentage of migrants in that stream of the total number of interprovincial migrants of that type. Theoretically, the maximum number of migratory streams (or cells in an OD matrix) is $756(=28 \times 27)$ for a 28 -unit case..$^{10}$ Of course, some of the OD cells are empty because there were no or negligible flows moving between those origins and destinations in the sample. As a result, the number of cases in the regression analysis range from 512 to 755 for different types (see Table 4, last row).

Regression results and interpretations

In order to test the differential effects of the above variables on different types of migration, we ran a multiple regression model separately for each type of migration (hukou, non-hukou, and rural labour migration). We also ran a model for all types combined ('all' migration). A table listing zero-order correlations for each independent variable with the dependent variable is in Appendix 2 for reference. The simple correlations show that among all the variables, FDI, and to a lesser extent, $D_{\mathrm{ij}}, A_{\mathrm{j}}, M_{\mathrm{ij}}, L_{\mathrm{i}}$ and $L_{\mathrm{j}}$, are weakly correlated with migration rates in most models, and with most signs in the anticipated directions. In the multiple regression analysis, in order to eliminate the multicollinearity problem, we have examined the correlations among the independent variables and decided to drop the variables $A_{\mathrm{j}}, P_{\mathrm{j}}, C_{\mathrm{i}}$ and $C_{\mathrm{j}}$ because of the strong correlations among them and with other variables. The results of the final models are reported in Table 4 . The $R^{2}$ values are reasonably high and the $F$-statistics are significant at the 0.01 level. Almost all the coefficients are also significant. Attention to each of the coefficients among different types of migrations allows us to gauge the differential effect of each variable (factor) on different types of migration, and to infer the underlying mechanisms at work in various migration circuits.

Firstly, there are four variables that produce uniformly positive or negative, and mostly significant, effects on the three migration types. The variables that respond positively are $A_{\mathrm{i}}$ and $F D I$, and negatively, $D$ and $P_{\mathrm{i}}$. These are all expected. $A_{\mathrm{i}}$ and FDI reflect very much the migration push (rural surplus labour) and pull (job opportunities) forces at work, as discussed before. The higher coefficients of 
FDI for the non-hukou types are also consistent with the fact that foreign-invested enterprises are often labour-intensive and hire predominantly non-hukou workers (see Zhao, 1995). The significant positive effects of $A_{\mathrm{i}}$ on rural labour migration (2.01) and non-hukou migration (0.93), much higher than that on hukou migration (0.50), also corresponds to our $a$ priori theory of rural surplus labour and rural labour migration.

Another consistency across the three types of migration is the dominant role of distance. In all the equations, $D$ is highly significant and has the expected negative sign. Migration decreases with distance because financial and psychic costs and uncertainty increase with distance. The coefficients range from -0.71 for non-hukou migration to -0.91 for rural labour migration, with -0.80 for hukou migration. Distance is more of a deterrent to migration for hukou migrants than for non-hukou migrants. This is consistent with what one sees looking at only the 30 largest flows, as shown in Figs $1 \mathrm{~b}$ and $1 \mathrm{c}$.

However, it appears that there is a dual structure in non-hukou migration. For those moving for work (rural labour migrants), the distance deterrent is the greatest. A number of the largest flows of rural labour are within short distances such as from Hebei to Beijing and Tianjin, from Anhui to Jiangsu, or from Guangxi to Guangdong. Among the largest streams, only migration from Sichuan is the exception. Some of the probable reasons for this may include greater uncertainties faced by these labour migrants because they rely mainly on themselves and/or informal networks to get (often temporary) jobs and accommodation. Rural labour migrants, mostly unmarried, tended to migrate to nearby places for work and maintained close contact with their home bases for support. A large part of non-hukou migration in the non-work categories is generated by marriage. They move over long distances, such as those from southwestern provinces to the east coast (Fan and Huang, 1998). This significantly reduces the distance coefficient on non-hukou migration in the regression.

More importantly, however, the hukou and non-hukou migrations demonstrate opposite responses in the remaining variables, $L L_{\mathrm{i}}, L L_{\mathrm{j}}$ and MS. The opposite signs of the coefficients between the hukou and the non-hukou types support the hypothesis that the two types of migration operate in structures of very different natures. Hukou migration was regulated by government, while rural labour was more a function of the 'free' market, similar to ruralurban migrants in other developing countries. The positive coefficient of $L L_{j}$ and negative coefficient of $L L_{\mathrm{j}}$ for non-hukou migration, and especially rural labour migration, are consistent with the population pressure postulate. With the coefficient of $A_{\mathrm{i}}$, they point to an important role for surplus rural labour (partly due to land scarcity) in generating rural labour migration. The coefficients of $L L_{\mathrm{i}}$ and $L L_{\mathrm{j}}$ for hukou migrants are just the opposite. While most IP hukou migrants tend to move shorter distances and are likely to move between provinces with similar environments, because of return flows of migrants from more sparsely populated frontier provinces such as Xinjiang to more densely populated and urbanised provinces, the coefficients of $L L_{\mathrm{i}}$ and $L L_{\mathrm{j}}$ are opposite to those for the non-hukou migration and rural labour migration. This contrast could be due to the significance of return migration in hukou migration, the motivation for which was more for family reunion than for work. Most of this type of return migration was from the less populated frontier provinces to the densely inhabited eastern region.

Looking at the coefficients of $F D I, L L_{\mathrm{i}}, L L_{\mathrm{j}}$ and $A_{\mathrm{i}}$ together shows that non-hukou migration moved away from provinces with a high percentage of farm employment and high land pressure, to destinations with job opportunities. One group of destinations was the frontier provinces where arable land was more plentiful and commercially less developed. Those provinces provided many job opportunities for semi-skilled labour migrants in traditional craft-type work (like shoe repairs and tailoring), construction and petty commerce, or unskilled farm jobs (Liu, 1991; Feng, 1993). The other group, which is more important, is those provinces with high rates of foreign investment and where factory jobs for unskilled labour migrants are available. For hukou migrants, foreign direct investment is also still a significant variable, but the value of the coefficient is only about half of that for non- 
hukou migrants.

Perhaps the clearest differentiation of the two migration circuits lies in the migration networks, which are crucial for generating non-hukou migration but not hukou migration. The MS coefficient is significant and strongly positive for non-hukou migrants. The coefficient is much higher for rural labour migration than for non-hukou migration, consistent with the point that non-hukou migration is more 'networked' with other migrants in the same group (Rozelle et al., 1997; Yan, 1998). Nonhukou labour migrants relied more on the help of friends and relatives in seeking jobs and adapting to the new environment of the destination. As for hukou migration, the MS variable has a very small negative sign and is not statistically significant. Unlike non-hukou migrants, hukou migrants depend more on official and formal channels and less upon informal help from friends and relatives who migrated earlier to the same destination. ${ }^{11}$

\section{CONCLUSIONS}

This paper has analysed migration in China by incorporating a major socioeconomic institution, the hukou system, in the analytical framework. We have first compared and contrasted the socioeconomic characteristics and geographical patterns of hukou and non-hukou migratory flows crossing provincial boundaries, and developed some hypotheses about the two migration circuits with different operating processes. It is found that these two types of interprovincial migrants shared some general demographic characteristics; they were dominated by young adults between the ages of 20 and 29, predominantly male and married, although rural labour had a higher percentage under the age of 20 and unmarried. These general features are very similar to those of migrants elsewhere, reflecting the active migratory stages in one's life cycle. There are also some substantial differences between hukou and non-hukou migrants in other socioeconomic characteristics. Hukou interprovincial migrants tended to originate from urban areas, had a highly skewed share of the collegeeducated, and were employed in higherskilled jobs, while non-hukou migrants were mostly from rural areas with much lower educational attainment. They were also mostly in occupations with lower skill levels. In jobrelated migration, hukou migrants tended to move through government and formal channels, while non-hukou migrants relied on their own, often informal, channels for jobs. In labour migration, except for return flows of those who migrated to frontier regions in the 1950s and 1960s, most hukou migration was much shorter in distance. Non-hukou labour migration, on the other hand, contained both long-distance and short-distance moves.

We then subjected our data to statistical tests based on a place-to-place migration model. We regressed the different migration rates by type with both the origin and destination factors, and, based on statistical analysis, we have identified the differential effect of the same variables on different types of migration. This is most clearly shown in the comparison between hukou migration and non-hukou migration (including the subtype of rural labour migration). While both of them were deterred by distance and moved to coastal provinces with high rates of foreign investment, the degrees of impact were not the same. Foreign investment, which is closely related to the creation of large numbers of low-skilled jobs in China, had a far greater impact in generating non-hukou migration. As predicted, rural labour migrants moved from provinces with high population pressure to those that were more favourably endowed, in line with neoclassical formulations. The data examined also show that non-hukou migration and rural labour migration are consistent with networked migration hypotheses. Hukou migration, however, displayed very different responses. It was not tied to the migration stock, and the directions of flows were quite the opposite. This suggests the strong likelihood of a different set of factors at work. Based on the detailed analysis of the two types of migrants, this paper sheds some light on the broad structure of Chinese internal migration, migrant behaviours and their conditioning factors in the transitional era. Our analysis illustrates that in the late 1980s the hukou system remained a relatively powerful institution in structuring migration. The paper also demonstrates the usefulness of existing migration theories in China when the subject of the 
analysis is properly disaggregated in a research design that takes account of an important dimension of Chinese society. As the non-hukou or market-related component increases in Chinese migration, one can expect that theories based on market economies will become increasingly relevant to China.

\section{ACKNOWLEDGEMENTS}

The authors would like to acknowledge the support provided by the US National Science Foundation (SBR-9618500), the Henry Luce Foundation, and the Center for Studies of Demography and Ecology, University of Washington. An earlier version of this paper was presented at the "Migration in Contemporary China' Workshop in December 1998 at UCLA, Los Angeles. We are grateful for the comments and suggestions of Dorothy Solinger, Denise Hare, Wang Feng, Cindy Fan, and two anonymous referees, and for the cartographic assistance of Alana Boland and Xiaohong Hou.

\section{NOTES}

(1) In that era, migration was seen primarily as a tool used by the state to accomplish specific goals of socialist economic development. Migration was presumably in accordance with state plans and done through mechanisms of labour planning and household registration, and it was not a subject for the public or even academics to discuss.

(2) In China, officially, only hukou migration is considered as qianyi ('migration'); the rest is merely renkou liudong (population movement or 'floating'). The term implies an expected temporariness; the transients are not supposed to (and legally should not) stay in the destination permanently, and they are often termed as temporary migrants, although many of them may stay or have stayed in the destination for years. Non-hukou migration also includes some short-term movement (visiting, circulation, and commuting). As will be explained later, our analysis excludes commuters, visitors, and other short-term migrants, partly due to the lack of data.

(3) We have included 'study or training' in this category. Most students in this category would receive job assignments upon graduation.

(4) Appendix 1 maps the names of all the provincial-level units in mainland China as of 1990.
(5) This is a conventional geographical delineation commonly used: 'Eastern' refers to Heilongiiang, Jinin, Liaoning, Beijing, Tianjin, Hebei, Shandong, Jiangsu, Shanghai, Zhejiang, Fujian, Guangdong, Guangxi and Hainan; 'Central' includes Nei Mongol, Shanxi, Henan, Anhui, Hubei, Hunan and Jiangxi; and 'Western' refers to Xinjiang, Qinghai, Gansu, Ningxia, Shaanxi, Sichuan, Guizhou, Yunnan and Tibet

(6) From the late 1950s to the early 1970s, large numbers of educated urban youths, especially in the coastal provinces, were resettled in the countryside and in frontier provinces under various government-sponsored programmes, including the rustication movements. Many of these people returned to their home towns in the late 1970s and the late 1980s.

(7) The model can be easily derived from the gravity model, $M_{\mathrm{ij}}=\left(P_{\mathrm{i}} P_{\mathrm{j}}\right) / D_{\mathrm{ij}}$ (see Schultz, 1982).

(8) Migration from region i to region $\mathrm{j}$ can be seen as one possibility among a group of mutually exclusive, discrete alternatives, specified in the following logistic model:

$$
P_{\mathrm{ij}}=\mathrm{e}^{2} \mathrm{ij} / \Sigma \mathrm{e}^{2} \mathrm{ij}
$$

where $\Sigma P_{\mathrm{ij}}=1$ and

$$
\begin{aligned}
& \qquad \begin{array}{r}
\mathrm{Z}_{\mathrm{ij}}=\alpha \\
+\beta_{1} \ln P_{\mathrm{i}}+\beta_{2} \ln P_{\mathrm{j}}+\Sigma \lambda_{\mathrm{m}} \ln X_{\mathrm{mi}} \\
+\Sigma \gamma_{\mathrm{n}} \ln X_{\mathrm{nj}}+\delta \ln D_{\mathrm{ij}}
\end{array} \\
& \text { therefore } \ln \left(P_{\mathrm{ij}} / P_{\mathrm{ii}}\right)=\alpha+\beta_{1} \ln P_{\mathrm{i}}+\beta_{2} \ln P_{\mathrm{j}} \\
& +\Sigma \lambda_{\mathrm{m}} \ln X_{\mathrm{mi}}+\Sigma \gamma_{\mathrm{n}} \ln X_{\mathrm{nj}}+\delta \ln D_{\mathrm{ij}}
\end{aligned}
$$

Since $P_{\mathrm{ii}}$ (stayer) is generally much larger than $P_{\mathrm{ij}}$ (mover from $\mathrm{i}$ to $\mathrm{j}$ ) and its variation is much smaller than that of $P_{\mathrm{ij}}$, we may replace the odds ratio of moving from $i$ to $j$ over nonmigration $\left(P_{\mathrm{ij}} / P_{\mathrm{ii}}\right)$ by gross migration rate from $\mathrm{i}$ to $\mathrm{j}\left(M_{\mathrm{ij}}\right)$, which leads us back to the equation (1) (Fields, 1982). This procedure shows that the double logarithmic model under certain circumstances is a good approximation to the logistic model (see Schultz, 1982).

(9) A potential problem is that migration is part of population increase, so there tends to be simultaneous bias in migration models using population size as an independent variable (Fields, 1982). This should not be a problem for Chinese migration since the relative size of Chinese migration is very small, with gross out-migration accounting for only about $1 \%$ of the total population.

(10) Hainan was not a province in 1985. In order to maintain data consistency with other variables, Hainan was included in Guangdong in the regression analysis. Data on migration to 
Tibet were not collected in the 1990 Census and Tibet was excluded from our analysis.

(11) Finally, to illustrate the usefulness of a disaggregated approach in understanding the complexity of the Chinese migration system, we have also run a regression model (model 'All') using exactly the same variables for interprovincial migration as the hukou and non-hukou migration combined. For those variables that have same sign for hukou and non-hukou migrations, the 'All' model is consistent, although the values of the coefficients may change. For example, the coefficient of FDI for 'All' migration lies between non-hukou and hukou migrations. But for those variables with opposite signs, the aggregated model definitely blurs the differences between disaggregated migration types and dilutes the results. Thus, for instance, the two migration circuits revealed by the land-labour ratios are replaced by a single set of contradictory results, which show that migrants came from and also went to also less populated provinces. The non-significant 'migration stock' coefficient also conceals the important role of the migration network in rural labour migration. In short, the vast differences between hukou and non-hukou migrations demand a disaggregated approach. The aggregated model cannot explain the migration patterns satisfactorily, and leave many complexities in the processes undetected.

\section{REFERENCES}

Banister, J. and Taylor, J. R. (1990) China: surplus labour and migration, Asian-Pacific Population Journal 4(4): 3-21

Brown, A. A. and Neuberger, E. (eds) (1977) Internal Migration: A Comparative Perspective (New York: Academic Press)

Castells, M. and Portes, A. (1989) World underneath: the origins, dynamics, and effects of the informal economy, in A. Portes et al. (eds) The Informal Economy: Studies in Advanced and Less Developed Countries (Baltimore: Johns Hopkins University Press) 11-37

Chan, K. W. (1988) Rural-urban migration in China, 1950-1982: estimates and analysis, Urban Geography 9: 53-84

Chan, K. W. (1994) Cities with Invisible Walls: Reinterpreting Urbanization in Post-1949 China (Hong Kong: Oxford University Press)

Chan, K. W. (1996a) Internal migration in China: an introductory overview, Chinese Environment and Development 7: 3-13

Chan, K. W. (1996b). Post-Mao China: a two-class urban society in the making, International Journal of Urban and Regional Research 20: 134-50
Chan, K. W. (1998) An analysis of consequences and policies concerning recent population migration in mainland China (in Chinese), Journal of Population Studies 19: 33-52

Chan, K. W. (1999) Internal migration in China: a dualistic approach, in F. Pieke and H. Mallee (eds) Internal and International Migration: Chinese Perspectives (Richmond, Surrey: Curzon Press) 49-71.

Chan, K. W. and Yang, Y. (1996) Inter-provincial migration in the post-1949 era: types, spatial patterns, and comparisons, Seattle Population Research Center Working Paper 96-13

Chang, S. (1996) The floating population: an informal process of urbanization in China, International Journal of Population Geography 2: 197-214

Chapman, M. and Prothero, R. M. (1985). Circulation in Population Movement: Substance and Concepts from the Melanesion Case, (London: Routledge and Kegan Paul)

Cheng, T. and Selden, M. (1994) The origins and social consequences of China's hukou system, China Quarterly 139: 644-68

Christiansen, F. (1990) Social division and peasant mobility in mainland China: the implications of hu-k'ou system, Issues and Studies, 26 pp. 78-91

Davin, D. (1999). Internal Migration in Contemporary China, (New York: St Martin's Press)

Day, L. H. and Ma, X. (eds) (1994). Migration and Urbanization in China, (Armonk: Sharpe)

Demko, G. J. and Joanna R. (1987) Socialism and its impact on urban processes and the city, Urban Geography, 8(4): pp. 289-292

Demko, G. J. and Roland J. Fuchs. (1977) Commuting in the USSR and Eastern Europe: causes, characteristics and consequences, East European Quarterly, 9: pp. 463-475

Ding, J. (1994) Zhongguo renkou shengji qianyi bieliuchang tezheng tan (Characteristics of causespecific rates of inter-provincial migration in China), Renkou yanjiu (Population Research) 1: 1421

Fan, C. C. (1996) Economic opportunities and internal migration: a case study of Guangdong Province, China. Professional Geographer 48(1): 2845

Fan, C. C. and Huang, Y. (1998) Waves of rural brides: female marriage migration in China, Annals of the Association of American Geographers, 88(2): pp. 227-251

Feng, J. (1993) Blind flows in towns in the Northwest, Renkou yanjiu (Population Research) 2: 60-61 and 57

Fields, G. S. (1982) Place-to-place migration in Colombia. Economic Development and Cultural Change 30(3): 539-558 
Forbes, D. and Thrift, N. (1987). Introduction, in D. Forbes and N. Thrift (eds) The Socialist Third World, (Oxford: Blackwell), pp. 1-26

Goldstein, S. and Goldstein, A. (1987a). Varieties of population mobility in relation to development in China, Studies in Comparative International Development, Winter, pp. 101-124

Goldstein S., and Goldstein A. (1987b). Migration in China: methodological and policy challenges, Social Science History, 11(1): pp. 85-104

Goldstein S., and Goldstein A. (1990). China, in C. B. Nam et al. (eds) International Handbook on Internal Migration, (New York: Greenwood Press), pp. 6384

Goldstein S., and Goldstein A. (1991). Permanent and temporary migration differentials in China (Honolulu: East-West Population Institute: Papers of the East-West Population Institute No. 117)

Goldstein S., and Goldstein A. (1993). Censuses and Surveys as Sources of Information on Permanent and Temporary Migration in China, Population Studies and Training Center Working Paper Series 93-02, Brown University

Gong, Y. (1994). 'Mingong chao' de qiluo (The Rise and Fall of the 'Tidal Wave of Peasant Labor' (Wuhan: Hubei chubanshe)

Greenwood, M. J. (1969) An analysis of the determinants of geographic labor mobility in the United States. Review of Economics and Statistics 51: 189-194

Greenwood, M. J. (1971) A regression analysis of migration to urban areas of a LDC. Journal of Regional Science 11: 253-262

Greenwood, M. J. (1975) Research on internal migration in the United States. Journal of Economic Literature 13: 397-433

Gurak, D. and Caces, F. (1992). Migration networks and the shaping of migration systems, in M. Kritz, L. L. Lim and H. Zlotnick (eds), International Migration Systems: A Global Approach (Oxford: Clarendon Press) 150-76

Hare D., (1998). Effects of job location on migrants' wages: evidence from Rural China, Paper presented at the Conference on Migration in Contemporary China, UCLA, 5 December 1998

Hare, D. (1999) 'Push' versus 'pull' factors in migration outflows and returns: determinants of migration status and spell duration among China's rural population, Journal of Development Studies 35(3), pp. 45-72

Harris, J. and Todaro, M. P. (1970) Migration, unemployment and development: a two-sector analysis. American Economic Review: 126-142

Hatton, T. J. and Williamson, J. G. (1994) What drove the mass migrations from Europe in the late Nineteenth Century? Population and Development Review 20(3): 533-559

Helgeson, A. C. (1978). Soviet Internal Migration and its Regulation Since Stalin: the Controlled and the Uncontrollable, PhD Dissertation, University of California, Berkeley

Honig, E. (1990) Invisible inequalities: the status of Subei people in contemporary Shanghai, China Quarterly, 122 (June), pp. 273-292

Jefferson, G. H. and Rawski, T. G. (1992) Unemployment, underemployment, and employment policy in China's cities. Modern China 18(1): 42-71

Kelliher, D. (1992). Peasant Power in China: The Era of Rural Reform, 1979-1989 (New Haven, CT: Yale University Press)

Kuznets, S. (1982). The pattern of shift of labor force from agriculture, 1950-1970. In M. Gersoritz et al. (eds). The Theory and Experience of Economic Development. (London: Geoge Allen \& Unwin), pp. 43-59

Lewis, W. A. (1954) Economic development with unlimited supplies of labour, Manchester School of Economic and Social Studies May: 131-191

$\mathrm{Li}, \mathrm{M}$. and $\mathrm{Hu}, \mathrm{Y}$. (1991) Liudong renkou du dachengshi fazhan de yingxiang ji duice (Impact of Floating Population on the Development of Large Cities and Recommended Policy) (Beijing: Jingii ribao chubanshe)

Li, S. (1994) Regional economic development and migration in China in the 1980s, Renkou yu jingji (Population and Economy), 3: pp. 3-8, and 16

Li, S.-M. and Siu, Y.-M.. (1997) A comparative study of permanent and temporary migration in China: the case of Donguan and Meizhou, Guangdong Province, International Journal of Population Geography, 3: 63-82

Liang, Z. and White, M. (1997) Market transition, government policies, and interprovincial migration in China: 1983-1988. Economic Development and Cultural Change: 45(2), pp. 321-339

Liu, A. P. (1991) Economic reform, mobility strategies and national integration in China. Asian Survey 31(5): 393-408

Liu, Q. (1995). Rural-Urban Migration Sample Survey in Jinan Municipality of China: Sample Design and Preliminary Results, Economics Working Paper, Australian National University

Lowry, I. S. (1966). Migration and Metropolitan Growth: Two Analytical Models. (San Francisco: Chandler Publishing)

Lucas, R. E. B. (1997). Internal Migration in Developing Countries, in M. R. Rozenzweig and O. Stark (eds.) Handbook of Population and Family Economics, (London: Elsevier Science), pp. 722787

Ma, L. (1995). Socialist migration: the case of 
mainland China, in Proceedings of the International Conference on the Population of Mainland China and Taiwan (Taipei: Population Research Center, National Taiwan University) 111-126

Ma, Z. and Liaw, K. (1997) Explaining hierarchical and interprovincial migrations of Chinese young adults by personal factors and place attributes: a nested logit anaysis. Mathematical Population Studies 6(3): 217-239

Mallee, H. (1988) Rural-urban migration control in the People's Republic of China: effects of the recent reform, China Information, 11(4): pp. 12-22

Mallee, H. (1995) China's household registration system under reform, Development and Change, 26: pp. 1-29

Mallee, H. (1996) In defence of migration: recent Chinese studies on rural population mobility, China Information, 10(3/4): pp. 108-140

Massey, D. S. et al. (1993) Theories of international migration: a review and appraisal, Population and Development Review, 19(3): pp. 431-466

Massey, D. S. et al. (1994) An evaluation of internal migration theory: the North American case. Population and Development Review 20(4): 699-75

Mueller, C. F. (1982) The Economics of Labor Migration: A Behavioral Analysis. (New York: Academic Press)

Navril, F. J. (1977) The socioeconomic determinants of migration and the level of aggregation. Southern Economic Journal 43: 1547-1559

Nielsen, F. (1994) Income inequality and industrial development: dualism revisited. American Sociological Review 59: 654-677

Nolan, P. (1993) Economic reform, poverty and migration in China, Economic and Political Weekly, June 26, pp. 1369-1377

Ofer, G. (1977). Economizing on urbanization in socialist countries: historical necessity or socialist strategy in A. A. Brown and E. Neuberger (eds.), Internal Migration: A Comparative Perspective, (New York: Academic Press) pp. 277-303

Papademetriou, D. G. and Martin, P. L. (eds), (1991). The Unsettled Relationship: Labor Migration and Economic Development, (New York: Greenwood Press)

Piore, M. (1979). Birds of Passage: Migrant Labor in Industrial Societies, (New York: Cambridge University Press)

Portes, A. and Walton, J. (1981). Labor, Class, and the International System, (New York: Academic Press)

Poston, D. L. Jr. and Yaukey, D. (eds), (1992). The Population of Modern China, (New York: Plenum Press)

Qian, W. (1996). Rural-Urban Migration and its Impact on Economic Development in China, (Vermont: Ashgate)
Ricketts, E. (1987) US Investment and immigration from the Carribbean. Social Problems 34: 374-387

Roberts, K. D. (1997) China's 'tidal wave' of migrant labor: what can we learn from Mexican undocumented migration to the United States, International Migration Review, 31: pp. 249-293

Rogers, A. (1967) A regression analysis of interregional migration in California. Review of Economics and Statistics 49: 262-267

Ronnas, P. and Sjoberg, O. (1993) Urbanization, central planning and Tolley's model of urban growth: a critical review, Geoforum 24(2): pp. 193204

Rozelle, S. et al. (1997). Poverty, Networks, Institutions, or Education, paper presented at the 1997 Annual Meeting of the Association for Asian Studies, Chicago, March 13-16

Sassen, S. (1988). The Mobility of Labor and Capital: A Study in International Investment and Labor Flow. (Cambridge: Cambridge University Press)

Schultz, T. P. (1982) Lifetime migration within educational strata in Venezuela: estimates of a logistic model. Economic Development and Cultural Change 30(3): 559-594

Sha, J. (ed). (1995). Gaige kaifang de renkou wenti yanjiu (A Study of Population Problems under Reform and Opening) (Beijing: Beijing Daxue chubanshe)

Shen, J. (1995) Rural development and rural to urban migration in China 1978-1990. Geoforum, 26: 395-409

Shen, Y. and Tong C. (1992). Zhongguo renkou qianyi (Population Migration in China), (Beijing: Zhongguo tongji chubanshe)

Sjaastad L. A. (1962). The costs and returns of human migration, Journal of Political Economy, 70: pp. 7080-93.

Skeldon, R. (1990). Population Mobility in Developing Countries. (London: Belhaven Press)

Smith, C. (1996). Migration as an agent of change in contemporary China, Chinese Environment and Development, 7(1 and 2): pp. 14-55.

Solinger, D. (1995a). The floating population in the cities: chances for assimilation? in D. Davis et al. (ed.). Urban Spaces: Autonomy and Community in Contemporary China, (Cambridge: Cambridge University Press), pp. 113-139

Solinger, D. (1995b). China's urban transients in the transition from socialism and the collapse of the communist 'Urban Public Goods Regime', Comparative Politics, 27(2): pp. 127-146.

Solinger, D. (1995c). Job Categories and Employment Channels Among the 'Floating Population', Paper presented for the Workshop on the Development of Labour Resource and Economic Development in China's Coastal Regions, Shantou University, 8-11 December 1995 
Solinger, D. (1999). Contesting Citizenship in Urban China: Peasant Migrants, the State and the Logic of the Market, (Berkeley: University of California Press)

State Council and SSB (1993) Tabulation on the 1990 Population Census of the People's Republic of China, Vol. 4, (Beijing: China Statistical Publishing House)

Tan K. C., (1993). Rural-urban segregation in China, Geography Research Forum, Vol. 13: pp. 71-83.

Taubman, P. and Wachter M. L. (1986). Segmented labor markets, in O. Ashenfelter and R. Layard (eds), Handbook of Labor Economics, Vol. 2, (Amsterdam: Elsevier), pp. 173-196

Todaro M. P. (1976). Internal Migration in Developing Countries, (Geneva: International Labour Office)

Wadycki, W. (1974). Alternative opportunities and interstate migration: some additional results. Review of Economics and Statistics 56: 254-257

Wan, G. (1995). Peasant flood in China: internal migration and its policy determinants. Third World Quarterly 16(2): 173-19.

Wang F. (1997). Invisible Walls Within Cities: Migration and Emergence of a Dual Society in Urban China, Paper presented at the Conference on Social Consequences of Chinese Economic Reform, Harvard University, 23-34 May 1997

Wang, F. and Zuo, X. (1997). Socialist Dualism and the Migration Process in China: The Case of Shanghai, Paper presented at Workshop on Rural Labor and Migration in 1990's China, University of California, Irvine, 26 April 1997

Wang, G. (1993). A Study of the Relationship of
Distance and Migration in Interprovincial Migration, Renkou yu jingji, 2: 1-6.

Xu, Y. and Shengzhu Gu, S. (1994). Dangdai renkou qianyi yu chengzhenhua (Contemporary Population Migration and Urbanization), (Wuhan: Wuhan daxue chubanshe)

Yan, S. (1998). Regional migration and mechanisms in 1990s China, Shehuixue yanjiu (Sociological Research), 2: pp. 67-74.

Yang, X. and Goldstein, S. (1990). Population movement in Zhejiang Province, China. the impact of government policies, International Migration Review, 24(3): pp. 509-533.

Yang, X. (1993). Household registration, economic reform and migration, International Migration Review, 27(4): pp. 796-818.

Yang, Y. (1994). Zhongguo renkou qianyi yu fazhan de changqi zhanlue (Internal Migration and Long-term Development Strategy of China), (Wuhan: Wuhan chubanshe)

Yang, Y. (1996). 'Temporary residents' in China: causes and characteristics, Chinese Environment and Development, 7(1 and 2): pp. 103-117.

Zhang, C. (1991). Rural population flows and income growth, Zhongguo renkou kexue (Chinese Population Science), No. 5: pp. 13-19.

Zhao, M. (1995). On migrant laborers in several Shanghai enterprises, (in Chinese) Zhongguo renkou kexue (Population Science of China), 3: pp. 43-48.

Zhou K. X. (1996). How the Farmers Changed China, (Boulder: Westview) 


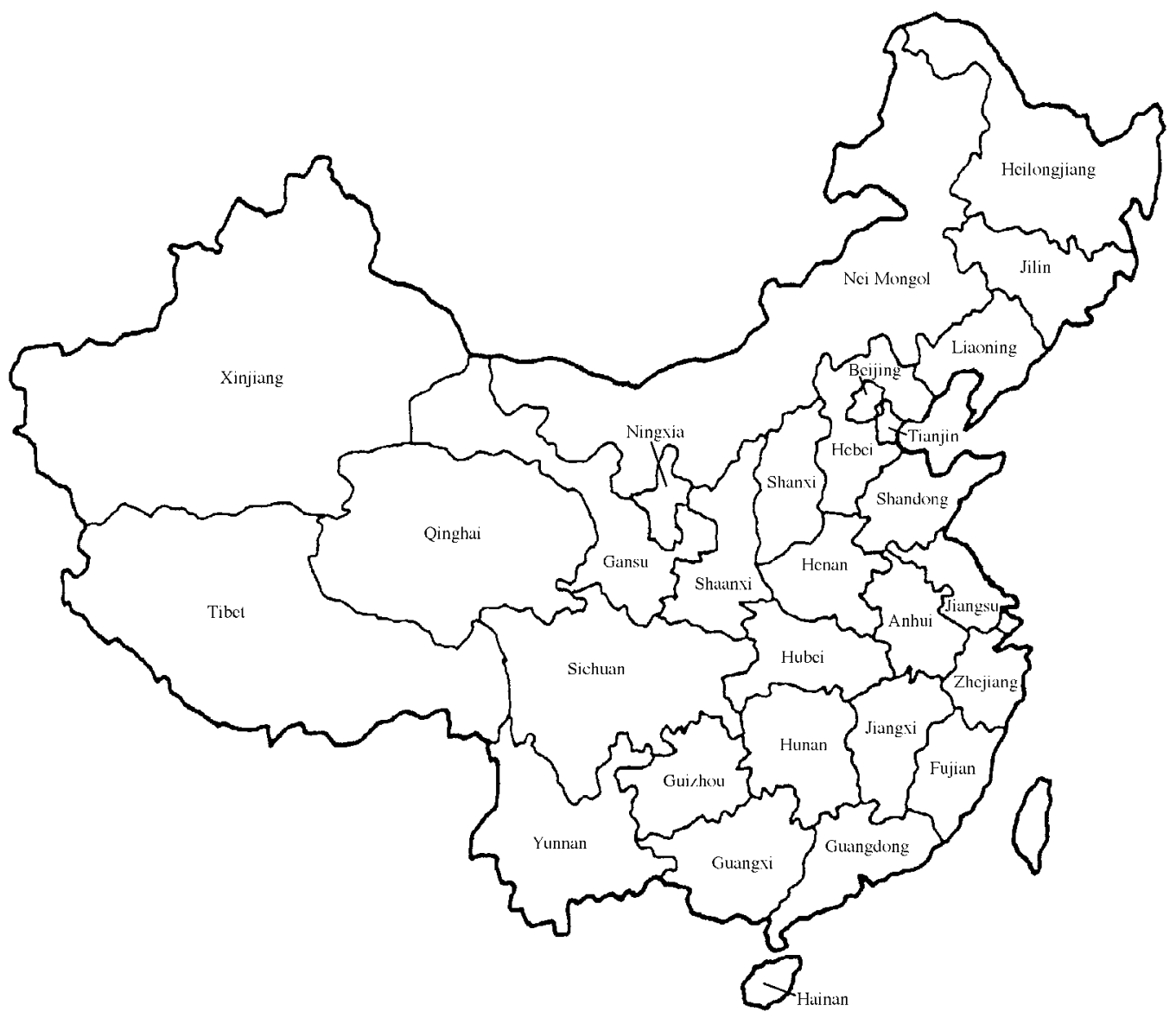

Appendix 1. Provincial level units in mainland China in 1990.

\section{APPENDIX 2}

Zero-order correlations between migration rates and independent variables.

\begin{tabular}{|c|c|c|c|c|}
\hline & \multicolumn{4}{|c|}{ Migration types } \\
\hline & Hukou & Non-hukou & Rural labour & All \\
\hline Distance from i to $\mathrm{j}\left(D_{\mathrm{ij}}\right)$ & $-0.390^{* *}$ & $-0.352^{* *}$ & $-0.345^{* *}$ & $-0.430 * *$ \\
\hline Origin population $\left(P_{\mathrm{i}}\right)$ & $-0.334^{* *}$ & -0.045 & -0.033 & $-0.125^{\star *}$ \\
\hline Destination population $\left(P_{\mathrm{j}}\right)$ & 0.008 & -0.077 & 0.002 & -0.060 \\
\hline Agricultural share at $\mathrm{j}\left(\hat{A}_{\mathrm{j}}\right)^{\prime \prime}$ & $-0.194^{* *}$ & $0.374^{* *}$ & $0.352^{* *}$ & $0.332^{* *}$ \\
\hline Agricultural share at i $\left(A_{\mathrm{i}}\right)$ & $-0.171^{* *}$ & $-0.069^{* *}$ & $-0.109 * *$ & 0.022 \\
\hline Consumption per capita at $\mathrm{j}\left(C_{\mathrm{j}}\right)$ & $0.190 * *$ & $0.055^{* *}$ & $0.180^{* *}$ & -0.029 \\
\hline Consumption per capita at $\mathrm{i}\left(C_{\mathrm{i}}\right)$ & $0.177^{* *}$ & $-0.259 * *$ & $-0.214^{* *}$ & $-0.264^{* *}$ \\
\hline Foreign direct investment $\left(P_{\mathrm{j}}\right)$ & $0.249^{* *}$ & $0.460^{* *}$ & $0.529 * *$ & $0.414^{* *}$ \\
\hline Migration stock $\left(M_{\mathrm{j}}\right)$ & $0.133^{* *}$ & $0.265^{* *}$ & $0.297^{* *}$ & $0.248^{* *}$ \\
\hline Land-labour ratio at i $\left(L L_{\mathrm{i}}\right)$ & $0.349^{* *}$ & $-0.015^{\star *}$ & $-0.212^{* *}$ & $0.150^{* *}$ \\
\hline Land-labour ratio at $\mathrm{j}\left(L L_{\mathrm{j}}\right)$ & $-0.139 * *$ & $-0.195^{* *}$ & $-0.352^{* *}$ & $-0.178^{* *}$ \\
\hline
\end{tabular}

Note:

** Significant at 0.01 level. 